\title{
Optimize of Least-Square Inverse Constrain Method of Geoelectrical Resistivity Wenner-Schlumberger for Investigation Rock Structures in Malalak Districts of Agam West Sumatra
}

\author{
Akmam ${ }^{1}$, Amir Harman², Putra, Amali ${ }^{3}$ \\ Jurusan Fisika FMIPA, Universitas Negeri Padang, Indonesia \\ Fakultas Teknik, Universitas Negeri Padang, Padang, Indonesia \\ akmam_db@fmipa.unp.ac.id
}

\begin{abstract}
ABSTRACK: Numerous studies have been conducted on an inversion method, focus on constraining factor, singuler value, speed of convergence. However, the result of inversion is not unique and bivalent. In this research, we optimize of Least-Square constrain by using damping factor. Th is method used for interpretation of the volumes and rock structure in Malalak Distric of Agam West Sumatra. This is undertaken because Malalak districts of Agam West Sumatra that passed by highway Padang and Bukittingi is a frequent area of landslide. Furthermore, the frequency of the landslide depends on the type of rock and the angle of the slope. The depth of the slide surface can be predicted by using the least squares inversion constrain method of Geoelectric Resistivity. Landslides resulted in disruption of transportation between the city of Padang and another district in Sumatra. Based on the above, to determine the rock's structure, the depth and tilt angle of the slide surface in Malalak districts Agam West Sumatra has to take place. Data obtained through Geoelectrical exploration using with automatic resistivity meter equipment. Constrains were obtained using the Marquat inversion method. The result of the research is first, the damping factor for structures which have wide range resistivity is 0.02 and the smallest damping factor is 0.015 . Second, the rock structure in Malalak of Agam consists of clay, sandstone, andesite, and limestone and dolomite.. Implementation this research can be used to develop mitigation of landslide deserter.
\end{abstract}

Keywords: Investigation, Slide surface, Geoelectrical Resistivity, Least-Square Inverse, Constraint

\section{INTRODUCTION}

The Geolectrical resistivity method is one of the oldest geophysical techniques which is intensively used for the investigation of the deep and shallow structure of the subsurface. By introducing the electrical current directly into the ground through a pair of current electrodes, the difference of the resulting voltage can be measured between the other pair of potential electrodes. The apparent resistivity of the subsurface can be calculated in this way in order to get the resistivity variation with depth. The depth of the penetration depends on the distance between the current electrodes. Increasing the depth of the penetration can be carried out by enlarging the distance between the current electrodes from a small distance in the beginning to larger distances at the end of the array.

This problem needs to get attention and scientific studies to avoid landslide recurrence. If repeated how the distribution of rock point locations that have the potential of landslides. The research can be used for landslide mit igation study in West Sumatera. The boundary between an avalanche material and the hard rock beneath which acts as a base is called the slip plane. The soft layer acts as a landslide material. Avalanche material is characterized by low resistivity value and landslide fields characterized by high resistivity material [1]. Electrical slip is characterized by the presence of two soil layers of highly contrasting resistance values [2], [8],[4],[5]). The slip field usually consists of low permeability and solid rock.
Assistance in the field of type resilient slip (200100) $\Omega \mathrm{m}$ [6]. Thus, electrically sloped field structures can be known based on the resistivity of these rocks.

In general, the slip surface has the following characteristics: first, the existence of the plating of the rock such as the surface of contact between the ground cover and the bedrock. Second, the presence of contact fields between rocks cracked with strong rocks. Third, the existence of contact fields between rocks that can pass water with rocks that can not pass water (impermeable). The depth of the slide surface which is the boundary between the moving and the fixed mass of the soil surface is essential for the description of avalanches [6]. The depth of a plane is useful to know how big the risk of landslide that occurred. Thus, the active landslide always moves on the plane at all times or throughout the season, while the old landslide can re-activate as long as there are trigger factors for landslides. The sliding surface is formed by the saturation of the water that accumulates and moves laterally above the surface of the soil layer or the rock that is difficult to penetrate with water called the waterproof layer [7]. If water penetrates to a waterproof layer, then the waterp roof surface of the waterproof layer will decay, thus becoming slippery. This slippery layer is called the slide surface. Layers that located over the plane of the slip will move a long the slope and out the slope. As a result, excessive volume of water will cause soil or rock instability on the slope.

The study used geoelectrical method to map the landslide potential areas that many researchers 
did before this research. The study of rock various of resistivity each location can be used to determine the slide surface, since the resistivity at the sounding point that contains clay can be related to the location where the weathered plane [8]. The surface of the slide surface is a layer of watercontaining clay having resistivity between (19.3 36.6) $\Omega \mathrm{m}$, there is at a depth between $(1.7-17$ meters $)$ and at a depth $(8,9-16,4)$ meters [9]. The $2 \mathrm{D}$ resistivity modeling [10], showed that the slide surface was at a depth between $(6-8)$ meters in the form of rotted Breccias with resistance type (30 118) $\Omega \mathrm{m}$.

Slide surface structure using profiles Tomography Multichannel Geolistrik method and drill hole found the material to compose the slide surface has low Resistivity (i.e. $\pm<80 \Omega \mathrm{m}$ ) [11]. Based on least-square inversion method optimized Geoelectric data interpretation found the slope of 33-6-45 and 19.3 meter depth with a translational slip type in Bukitlantik Padang [12]. The range of the rocks resistivity in situ in Bukitlantik Padang vulnerable areas between (4.55-94.1) $\Omega$ m using a time-lapse approach [13]. The surface of a slope field having a $300 \Omega \mathrm{m}$ type of resistance is a limestone block surrounded by Clay and Clayed Soil (Marl) having a lower resistivity [27].

The obsolete part of the Cretaceous Rock block is where the mass of wheels (slip plots) or triggers of collapsed rocks [14] [15]. Zone with type resistance $(<10 \mathrm{ohm}-\mathrm{m})$ at the depth (1100 1500) meters is a combination of Clays and Chinshui Shale is a fault zone [16] [35]. This shows that in the weathered zone has a low resistance type. The subsurface rock type resistance can be explored by the geometrical method of resistance of the Wenner-Schulumberger configuration type. Interpretation of field data measurement data can be done by an inversion method. Problems encountered in interpreting data by inversion method are unique of results [17], [18] and yield stability [19], but to date the inversion method is still the best for interpreting the Geoelectric measurement data. In order for the results of interpretation to approach a unique and stable result need to be optimized factors that influence it, such as damping factor inversion. Inversions can display the same response from three or more different models. This can cause errors in the parameter interpretation. This problem can be significantly reduced by using the Joint Inversion methods [17], [18],[20] which are then perfected by providing a lateral constraint [21],[22], but the results are still not optimal. One alternative solution to overcome the above problem is to optimize the damping factor on the least-squares smoothness-constrain inversion method.

Geolistrik method can be used to estimate the condition of subsurface geology such as rock types in the form of rock type resistance values below the surface [23], [24], [25]). Earth is not a structure that has a calculated equation [26], [27]

$$
\rho_{a}(x)=x^{2} \int_{0}^{\infty} T(\lambda) J_{1}(\lambda x) \lambda d \lambda
$$

which $\rho_{a}$ is a apparent resistivity. where, $s$ is half the current electrode spacing in Wenner-Schlumberger electrode configuration, $\mathrm{J}_{1}$ denotes the first-order Bessel function of the first kind and $\lambda$ denotes the integral variable. The resistivity transform function, $\mathrm{T}(\lambda)$, is given by the recurrence relationship[12], [28] as follows:

$$
T_{i}(\lambda)=\frac{T_{i+1}(\lambda)+\rho_{i} \tanh \left(\lambda h_{i}\right)}{\left[1+\frac{T_{i+1}(\lambda)+\rho_{i} \tanh \left(\lambda h_{i}\right)}{\rho_{i}}\right]}, i=n-1 \ldots 1
$$

where, $n$ denotes the number of layers, $\rho_{i}$ and $h_{i}$ are the resistivity and thickness of the ith layer, respectively.Non-linear least-squares inversion scheme iteratively updates the model parameters in each step with the use of a correction vector which is the solution of a set of normal equations. Inversion of geoelectrical data is an ill-posed problem [17],[29].Singular Value Decomposition (SVD) is well-known technique used in many areas of applied sciences including the earth sciences [28]. It can be easily applied to small scale geophysical problems. However it must be noted that the use of SVD is not logical for large scale problems. The large scale problems can be solved either explicitly or imp licitly using iterative methods like conjugate gradients to solve by using SVD in the inversion scheme. The damped leastsquares solution have been modified by ([18]

$$
\Delta \mathbf{m}=\mathbf{V} \operatorname{diag}\left\{\frac{1}{\lambda_{i}^{2}+\varepsilon^{2}}\right\} V^{T} V S U^{T} \Delta d
$$

and the parameter correction vector can be expressed as:

$$
\Delta m=V \operatorname{diag}\left\{\frac{\lambda_{i}}{\lambda_{i}^{2}+\varepsilon^{2}}\right\} U^{T} \Delta d
$$

So, because of this correction was not getting the optimal result, eqution (4) is modified by using emperis approach, we get damping factor as follow

$$
\Delta m=V \operatorname{diag}\left\{\frac{0.92 \lambda_{i}}{\lambda_{i}^{2}+\varepsilon^{2}}\right\} U^{T} \Delta d
$$

\section{METODOLOGY}

This research is an explorative research. Interpretation results using the least-squares smoothness-constrained inversion least-residence method Geolistrik Type Resistivity data are used to obtain the slope and depth of the slip surface area in the potentially landslide area. The collection of exploration results is used to estimate the distribution of potentially landslide disaster areas in Malalak Agam West Sumatra. The location of the measurement is the longsong-prone area in Malalak Agam of West Sumatra with coordinates $\quad(00.22 .488$ S, $100.16 .593 \quad$ E) - 
$(00.25,496$ S, $100,17,214$ E). Perta location

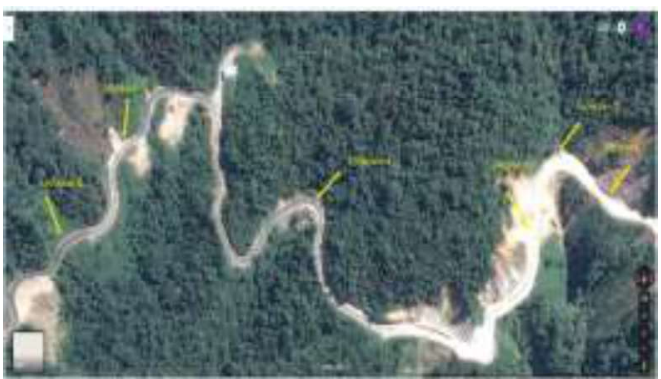

measurement as Figure 1

Figure 1: Measurement Locations in Kecamatan Malalak Agam West Sumatra (Google Map, September 23, 2017, [5]).

The arrangement of electrodes in the Wenner-Schlumberger configuration is shown in Figure 2

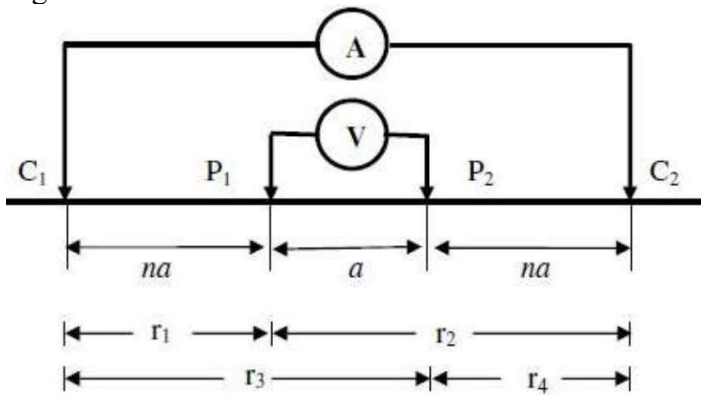

Figure 2. Configuration of Wenner- Schulamberger configuration electrode.

The apparent resistivity of measurement is calculated by the equation:

$$
\rho_{a}=2 n \pi a(n+1) \frac{\Delta V}{I}
$$

The main equipment used to obtain apparent resistivity is the multichannel Automatic Resistvity System GF Instrument (ARES) with the Ares-G4 model specification of Cheko production, belonging to the FMIPA UNP Padang. The analyzed data are interpreted by comparing the resistance value of the type obtained from the processed data with the type resistance table based on the reference and also compared with the geological condition in the direction of the measurement. The apparent resistivity data are interpreted using a Least-Square inversion in order to obtain a $2 \mathrm{D}$ resistivity cross section. The 2D section of resistivity obtained is divided into several grids. The resistance types of some obtained are interpreted by the optimized Least-Square inversion method using damping. Based on the obtained 2D cross-section, it is known that the location where the layer has a true resistivity value is contrast. Based on the true resistivity price obtained, the geological structure of the disaster prone area and the reference type reference table are estimated to be the type of rock or mineral prone area of the landslide. Based on the 2D cross-section, it is known to estimate the slope and depth of the slipprone area in West Sumatera. Damping inversion used is a factor that has been obtained through cutting the value of singguler (Equation 5)

\section{RESULTS AND DISCUSSIONS}

a. Damping factor. Damp ing factor to optimize the result of interpretation method Inversion leastsquares smoothness-constrain Geolistrik resistivity data is designed using a method of intersecting singguler (SVD). Base on equation (5), we get the damping factor for the wide and minimum range resistivity of 0.2 and 0.003 respectively. Then, the value of the damping factor for the first layer is 30 that we call $(0.3$, 0.003 and 30 ).

b. Characteristics of the slide surface at $\left(00^{\prime} 22.259\right.$ S, $100^{\prime} 17,300$ ') up to $\left(00^{\prime} 25.488 \mathrm{~S}, 100^{\prime} 16,412^{\prime}\right.$, $100^{\prime} 16,318$ '). 2-D cross-section resistivity in the first location as shown in Figure 3 dan Figure 4

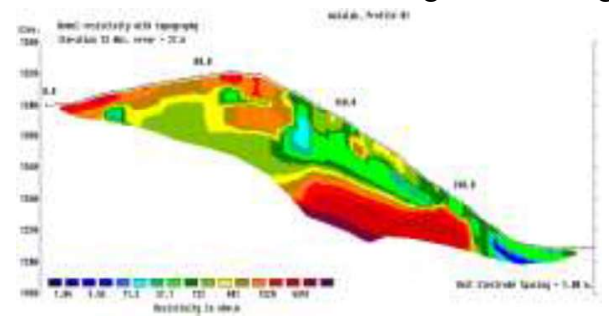

Figure 3: A 2-D cross section of the slide surface at $\left(00^{\prime} 22.259 \mathrm{~S}, 100^{\prime} 17,300 \mathrm{~S}^{\prime}\right)$ up to $\left(00^{\prime} 25.488 \mathrm{~S}\right.$, $100^{\prime} 16,412$ ', 100 '16,318 ') with general the damping factor $((0.02,0.013$ and 5$)$

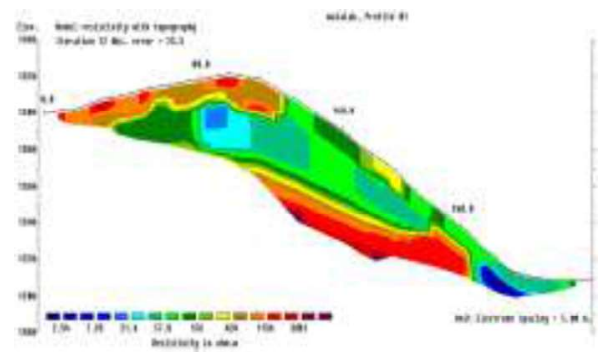

Figure 3.b

Figure 4: A 2-D cross section of the slide surface at $\left(00^{\prime} 22.259 \mathrm{~S}, 100^{\prime} 17,300^{\prime}\right)$ up to $\left(00^{\prime} 25.488 \mathrm{~S}\right.$, $100^{\prime} 16,412$ ', $100 ' 16,318$ ') with optimization damping factor $(0.2,0.003$ and 20$)$

Figures 3 and 4 show that the cross -section obtained through the use of optimized damping factors provides a description of the rock structure and clear boundary plane. However, both approaches produce the same type and structure of rocks. The rock structure in the Malalak Agam regency of West Sumatra consists of Clay, Limestone Sandstone, Andesite Dolomite and Gravel. Clay (Resistivity $=22.3 \mathrm{Ohm}-30 \mathrm{Ohm}$ ) is 
found between the Andesite rocks (Resistivity = 481 Ohm-meters - 3267 Ohm-meters, [24],[25]. This type of coating shows the presence of a slide in this position [30], [8]. The boundary between the mass of moving material and the stationary is called the slide surface [31]. The material that moves above the slide surface is called the landslide. So, Material movement is caused by disruption of soil stability or slope constituents.

The comparis on of resistivity results allows us to determine the critical landslide criterion level, where this condition contributes to developing a landslide early warning system using the Geoelectrical method [32]. A low-type resistivity zone that forms a sloping arch consisting of clay and has a high degree of saturation is a plane, as observed in the borehole [33]. At the location of large avalanche possibility, if in this region washed down with a large volume [34]. Rock resistivity anomalies in this area are estimated due to Dolomite rocks. Dolomite is a rock solid and hard which is a waterproof rock, but easy to experience weathering. The sliding surface of this track has a slope of 43,420 , with a layer thickness of 15 meters (Figure 3) [5]. Based on Figure 4, we got the slope of the slide surface was 42,350 and layer thickness was 13 meters. This data show that slide surface that we found by high damping factor was produce the clear of slide surface. The effects of Clay on Dolomite's aid are as sliding surface surface [35],[6]). This is what triggers this area is often landslide, when washed down by heavy rain.

c. Characteristics of the slip plane at $\left(00^{\prime} 22.259\right.$ S100'17,300 ') to (00'24.576 S, 100'16,596'). 2 $\mathrm{D}$ cross-section resisitivity at the second location as shown in Figure 4

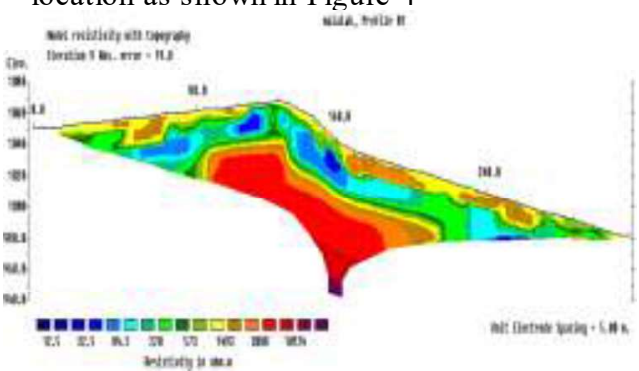

Figure 5: A 2-D cross section of the slide surface at $\left(00^{\prime} 22.259 \mathrm{~S} 100 ' 17,300 \mathrm{C}^{\prime}\right)$ to $\left(00^{\prime} 24.576 \mathrm{~S}\right.$, $100^{\prime} 16,596$ ') with general the damping factor $((0.02,0.013$ and 5$)$

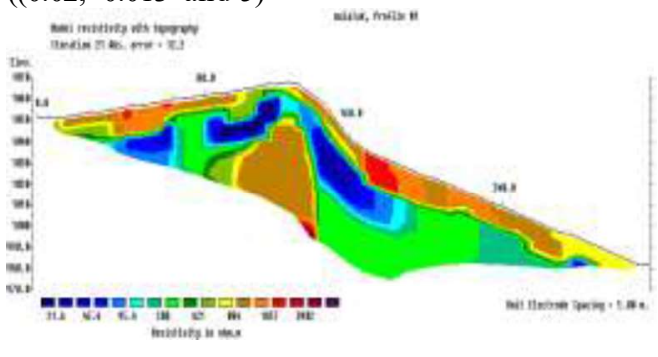

Figure 6: A 2-D cross section of the slide surface at $\left(00^{\prime} 22.259 \mathrm{~S} 100^{\prime} 17,300 \mathrm{\prime}^{\prime}\right)$ to $\left(00^{\prime} 24.576 \mathrm{~S}\right.$, $100^{\prime} 16,596$ ') with optimization damping factor $(0.2,0.003$ and 20$)$

Figure 5 and Figure 6 show that there is Gravel (Resistivity $=297$ Ohm-meters -1653 Ohm-meters) found between Andesite rocks (Resistivity $=481$ Ohm-meters - 3267 Ohmmeters, Telford, et al., 1975, Reynold, 1997). At Figure 5, there is no slip field because it does not comply with the requirements of landslide (Bari, 2011, Joab \& Andrews, 2009, Akmam, et al., 2014, Akmam, et al., 2015). Landslides with large volumes are expected to occur rarely at this location. However, this field of inactivity is inactive because at this location which acts as a field of slip is Gravel is not water-resistant. Smallscale landslides may occur at this location because the hill at this location is quite steep. However, in Figur 6, the 2D resistivity cross-section is the result of least-square inversion with optimized damping factor resulting in a $2-\mathrm{D}$ cross-sectional interpretation showing the presence of a slip plane. So, we can say that in there are the slip surface at $\left(00^{\prime} 22.259 \mathrm{~S} 100^{\prime} 17,300 \mathrm{~S}^{\prime}\right)$ to $\left(00^{\prime} 24.576 \mathrm{~S}\right.$, $100^{\prime} 16,596$ ') which have the depth and the angle of slide surface are 43.210 and 23 meters. This is not the active slide surface.

\section{CONCLUSIONS AND IMPLEMENTATION}

a. Damping factor to optimize results of interpretation method Inversion least-squares smoothness-constrain data Geolistrik resistivity in this research earn respectively, for wide range resistivity and minimu $m$ factor damping are 0.2 and 0.003 . Then, the value of the damping factor for the first layer is 30 .

b. The rock's structure in Malalak Agam District West Sumatra consist of consists of Clay, Limestone Sandstone, Andesite Dolomite and Gravel.

c. The depth and the angle of the slip surface at $\left(00 ' 22.259 \mathrm{~S} 100 ' 17,300\right.$ ' $\left.^{\prime}\right)$ to $(00 ' 24.576 \mathrm{~S}$, $\left.100^{\prime} 16,596^{\prime}\right)$ are 40.380 and 16.5 meters. Th is is the active slide surface. 4 . The depth and the angle of the slip surface at (00'22.259 S100'17,300') to (00'24.576 S, 100'16,596') are 43.210 and 23 meters. This is not the active slide surface.

d. The implementation of the results of this study is at coordinates (00'22.259 S100'17,300') to $\left(00^{\prime} 24.576 \mathrm{~S}, 100^{\prime} 16,596^{\prime}\right)$ must be planned mitigation of the landslide disaster well. Mitigation that can be done is to make a landslide dam with a depth of 17 meters. Dams that must be able to pass water, so that the ground masses do not push the dam during heavy rain. 


\section{REFERE NCES}

[1] A.Gemizzi, G. Falalakis, P.Eskioglou, C. Petalas. 2011. Evaluating Landslide Susceptibility Using Enveronmenal Factors, Fuzzy Membership Function and GIS, Global NEST Journal, 2011, 13(1), 28-40, , e-Journal.

[2] Chi-Yuen Wang, Sundaram, P.N., Goodman, R.E., Electrical Resistivity Charges in Rock During Frictional Sliding, Rock Friction and Earthquakes Prediction Contribution to Cuurent Research in Geophysics, 1978, 6, 717-731

[3] Calvello, M., Cuomo, S., \& Ghasemi, P. (2017). The role of observations in the inverse analysis of landslide propagation. Computers and Geotechnics, 92, 11-21

[4] Chambers, J.E., P.B. Wilkinson, D.A. Gunn, R.D. Ogilvy, G.S. Ghataora, M.P.N. Burow,Tilden, S.R, (2007), Non-invasive characterization and monitoring of earth embankments using Electrical Resistivity Tomography (ERT)., British Geological Survey, e-Journal, download September 2014.

[5] Akmam,A., A mir Harman, Putra, A mali, (2017), Investigation Of Slip Surface In Malalak Districts Of Agam West Sumatra Using Geoelectrical Res istivity Wenner-Schlumberger, Journal of Environmental Studies and Sciences (Submit)

[6] Fransheri, A., Ludyig, K., and Foto, D. Geophysical landslide investigation And Prediction In The Hydrotechnical Works. Journal Of The Balkan Geophysical Society. 1998. 1(3).

[7] Chang, Jui-Ming, Chen, Hongey, Jou, Ben Jong-Dao Jou, Tsou, Nien-Chiao, Lin , GuanWei, (2017), Characteristics of rainfall intensity, duration, and kinetic energy for landslide triggering in Taiwan, Engineering Geology, S0013-7952(17)31458-8, doi: 10.1016/j.enggeo.2017. 10.006

[8] Joab, M. J., \& Andrewsb, M. (2009). Investigating Slope Failures Using Electrical Resistivity: Case Studies. Association of Professional, 66.

[9] Darsono, Bambang, N, Legowo, B., (2012), Identifikasi Bidang Gelincir Pemicu Bencana Tanah Longsor dengan Metode Resistivitas 2 Dimensi di Desa Pablengan Kecamatan Matesih Kabupaten Karanganyar, Indonesian Journal of Applied Physics (2012) Vol.2 No.1, Download, 20 April 2017,

[10] Zaroh, I., Permanajati, I., Haryadi, A., Wihantoro, dan Azis, A.N., (2016), Investigation of Landslide Aviation Field With Method of Type Resistance and Tests of Soil Plasticity Character (Case Study In Bukit Pawinihan, Sijeruk, Banjarmangu,
Banjarnegara), Dinamika Rekayasa Vol. 12 No. 2.

[11] M. Fressard, A., O. Maquaire A, Y. Thieryb, R. Davidsona, C. Lissak, (2016), Multimethod characterisation of an active landslide: Case study in the Pays d'Auge plateau (Normandy, France), Geomorphology 270 (2016) 22-39 www.elsevier.com/locate/ geomorph, (diunduh pada tanggal 13 April 2017)

[12] Akmam, Irefia, R., D., Silvia D. , S., Jemmy, R., 2015, Optimition Of Least Squares Methods Smooth Constrain Using Occam's Inversion Geoelectric Resistivity DipoleDipole Consfiguration For Estimation Slip Surface, The International Conference on Mathematics, Science, Education and Technology, Inna Muara Hotel and Convention Center Padang, Indonesia, October 22, hal: 178-185

[13] Mahrizal, Fauzi, A, Akmam, (2015), Monitoring Technology Development Geoelectric Time-Lapse To Monitor The Prone To Landslide In Padang Using Methods Geoelectric Time-Lapse Resistivity Inversion In Wenner And Schlumberger Configuration, The International Conference on Mathematics, Science, Education and Technics, Inna Muara Hotel and Convention Center Padang, Indonesia. Hal: $197-204$.

[14] Bell, R., Jan-Erik Kruse, AIejandro Garcia, Thomas Glade, Bonn, Andreas Hördt, Braunschweig, (2006), Subsurface Investigations of Landslides Using Geophysical Methods Geoelectrical Applications In The Swabian Alb (Germany), Geographica Helvetica Jg. 61 2006/ Heft 3), Hal. 201-208, (diunduh pada tanggal 20 April 2017)

[15] Chih-Wen Chiang, Martyn J. Unsworth, Chow-Son Chen, Chien-Chih Chen, Andrew Tien-Shun Lin, and Han-Lun Hsu, 2008, Fault Zone Resistivity Structure and Monitoring at the Taiwan Chelungpu Drilling Project (TCDP), Terr. Atmos. Ocean. Sci., Vol. 19, No. 5, 473-479, October 2008, (diunduh pada tanggal 20 April 2017)

[16] Chang, Jui-Ming, Chen, Hongey, Jou, Ben Jong-Dao Jou, Tsou, Nien-Chiao, Lin , GuanWei, (2017), Characteristics rainfall intensity, duration, and kinetic energy for landslide triggering in Taiwan, Engineering Geology, S0013-7952(17)31458-8, doi: 10.1016/j.enggeo.2017.10.006

[17] Vozoff, K., Jupp, D.L.B.,Joint inversion of geophysical data. Geophysical Journal of the Royal Astronomical Society 1975, 42, 977991

[18] Akmam, Doddy Sutarno, Pemodelan Inversi Satu Dimensi Data Magnetotellurik 
Memodifikasi Inversi Occam dengan Pemotongan Nilai Singuler, Jurnal Kontribusi Fisika Indonesia, Jurusan Fisika FMIPA ITB Bandung, 1997, 8(2), 97-106.

[19] Abdul-Nafiu, A.K, Nawawi, M. M. N., Khiruddin, A, Ishola, K. S and Abdulrahman, A. 2013. Effects Of Electrode Spacing and Inversion Techniques On The Efficacy of $2 d$ Resistivity Imaging To Delineate Subsurface Features, American Journal of Applied Sciences, 10 (1): 64-72,

[20] Møller, I, Bo H. Jacobsen, and Niels B. Christensen, (2014), Rapid inversion of 2-D Geoelectrical Data by Multichannel Deconvolution, Geophysics, 66(3),800-808

[21] Yilmaz, S., 2007, Investigation of Gürbulak Landslide Using 2D Electrical Resistivity Image Profiling Method (Trabzon, Northeastern Turkey), Journal of Environmental \& Engineering Geophysics, June 2007, v. 12; issue. p. 199-205.

[22] Souisa ,Matheus, Hendrajaya, L, Handayani, G, (2015), Determination of Landslide Slip Surface Using Geoelectrical Resistivity Method at Ambon City Moluccas-Indonesia, International Journal of Emerging Technology and Advanced Engineering, Website: www.ijetae.com (ISSN 2250-2459, ISO 9001:2008 Certified Journal, Volume 5, Issue 7, July 2015

[23] Akmam dan Nofi, Y,S., 2013. Analysis of Rock Structure With Inversion Method Smoothness-Constrained Least-Squares Geolistrik Data Schlumbergesr Configuration At Padang State University Fresh Water Campus, Prosiding Semirata FMIPA Univers itas Lampung, 45-51

[24] Telford, W.M. Geldart, L.P, Sheriff R.E and Keys, D.A. Applied Geophysics. USA: Cambridge University Press. 1976.

[25] Reynolds, J.M. An Introduction to Applied and Environmental Geophysics. New York: Jhon Geophysicsin Hidrogeological and Wiley and Sons Ltd, 1997.

[26] Grandis, Hendra, (2009), Introduction to Geophysical Inversion Modeling, Indonesia Geophysical Expert Association (HAGI), 2009.

[27] Akmam dan Nofi, Y,S., 2013. Analysis of Rock Structure With Inversion Method Smoothness-Constrained Least-Squares Geolistrik Data Schlumberger Configuration At Padang State University Fresh Water Campus, Prosiding Semirata FMIPA Universitas Lampung, 45-51
[28] Maiti,S., G. Gupta, V. C. Erram, and R. K. Tiwari, (2011), Inversion of Schlumberger resistivity sounding data from the critically dynamic Koyna region using the Hybrid Monte Carlo-based neural network approach, nonlinear Processes in Geophysic, Nonlin. Processes Geophys. 18, 179-192, 2011, www.nonlin-processes-

geophys.net/18/179/2011/ doi:10.5194/npg18-179-2011

[29] Degroot-Hedlin, Catherine and Steven Constable, Occam's Inversion and the North American Central Plains Electrical Anomaly, Journal Geomagnetic Geoelectric, 1993, 45,985-999.

[30] de Bari, C., Lapenna, V., Perrone, A., Puglisi, C., \& Sdao, F. (2011). Digital photogrammetric analysis and electrical resistivity tomography for investigating the Picerno landslide (Basilicata region, southern Italy). Geomorphology, 133(1), 34-46.

[31] Zare, M. A., Haghshenas, E., \& Jafari, M. K. (2017). Interpretation of dynamic response of a very complex landslide (Latian-Tehran) based on ambient noise investigation. Soil Dynamics and Earthquake Engineering, 100, 559-572.

[32] Antonio Carlos Martins, Vagner Elis, Giorgio de Tomi, Jorge Bettencourt and Tatiane Marin, 2015, Resistivity and Induced Polarization to Support Morphological Modeling in Limestone Mining, Geofísica Internacional (2016) 55-4: 227-238. (diunduh pada tanggal 20 April 2017)

[33] Lapenna, V., Perrone, A., Piscitelli, S., (2012), Electrical Tomography for landslide monitoring: state-of-the-art and an overview of recent results in Southern Italy, EMSEV Gotemba Kogen Resort, Gotemba, Japan October 1-4, 2012. (diunduh pada tanggal 20 April 2017)

[34] Sass, O., Bell, R., Glade, T., 2007, Comparison of GPR, 2D-resistivity and traditional techniques for the subsurface exploration of the Oschingen landslide, Swabian Alb (Germany), Geo morphology 93 (2008) 89-10

[35] Loke, H.M, Res2Dinv Rapid 2D Resistivity \& IP Inversion, for Windows XP/Vista, Goetoma Software Malaysia, 2009

[36] Perrone, A., Sabatino, P., and Vincenzo, L. Electrical Resistivity Tomographies For Landslide Monitoring: a Review. Berichte Geol. B, 2012.-A.93. ISSN 1017-8880 